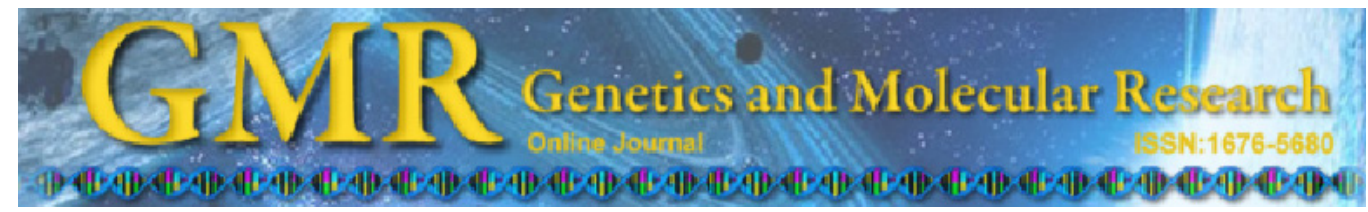

Short Communication

\title{
Non-invasive sex identification of the white- bellied sea eagle (Haliaeetus leucogaster) through genetic analysis of feathers
}

\author{
D.M. Naim, S.A.M. Nor and M.H. Baharuddin \\ Correspondence authors: D.M. Naim \\ E-mail: darlinamdn@usm.my \\ Genet. Mol. Res. 10 (4): 2505-2510 (2011) \\ Received March 14, 2011 \\ Accepted September 11, 2011 \\ Published October 13, 2011 \\ DOI http://dx.doi.org/10.4238/2011.October.13.7
}

School of Biological Science, Universiti Sains Malaysia, Minden, Penang, Malaysia

\begin{abstract}
The white-bellied sea eagle, Haliaeetus leucogaster, displays reversed sexual size dimorphism and is monomorphic for adult plumage coloration. Early attempts to identify sex in sexually monomorphic birds were based on morphological or chromosomal characters, but since avian W-specific DNA sequences were identified, PCR amplification has become commonly used for molecular sexing. We used a PCR test employing primers that amplify two homologous fragments of both the CHD-W gene, unique to females, and the CHD-Z gene, occurring in both sexes. This test was applied to five individuals of H. leucogaster from the Malacca Zoo and to male and female domestic chickens, Gallus domesticus, for comparison. All individuals were sexed successfully with high reproducibility. We conclude that this PCR-based test with feathers as the DNA source is a reliable sexing method for $H$. leucogaster. This sexing technique is objective and non-invasive and could be used to test sex ratio theories, as well as to help improve conservation and management actions for captive breeding program of this species in Malaysia.
\end{abstract}

Key words: White-bellied sea eagle; Sex identification; Accipitridae; Conservation 


\section{INTRODUCTION}

Sex determination can provide researchers with important information regarding the ecology and behavior of bird species (Helander et al., 2007), and also provides valuable insights into their breeding strategies, conservation and management programs (Helander et al., 2007; García et al., 2009; Naim et al., 2011a). Adults of many avian species, particularly raptor, exhibit sexual size dimorphism even at the nestling or subadult stages (Millar et al., 1997; Helander et al., 2007), enabling sex determination based on morphometry (Helander et al., 2007). However, morphometric methods are typically inaccurate, especially if the traits used for sex discrimination also show geographical variation, which is known to occur in many bird species (Shephard, 2004). Moreover, problems can arise when the characteristics of dimorphism differ among populations or when sampling time is not consistent during their nestling period (Setiawan et al., 2004).

A crucial point in any kind of free-ranging animals is the sampling that must be simple, not stressing and non-invasive (Sacchi et al., 2004). Surgical procedures such as laparoscopy are intrusive and represent a risk to the individual; consequently, such techniques are generally avoided with endangered species (Millar et al., 1997; Griffiths et al., 1998). Moreover, traditional genetic techniques for sexing birds including cytogenetics and isozymes, often fail to provide conclusive and reliable tests for many bird species (Millar et al., 1997). In this respect, a growing number of studies are utilizing non-invasively collected samples (i.e., feathers, hair, feces, etc.) to characterize ecological or demographic attributes of populations that are either difficult or impossible to determine by more traditional means (Rudnick et al., 2007). While hairs and feces have proved to be suitable non-invasive materials in mammals (Naim et al., 2009), bird feathers are rarely used (Segelbacher, 2002).

The white-bellied sea eagle, Haliaeetus leucogaster [Order: Falconiformes (Gmelin, 1788)], is a large territorial species associated with coastal regions, lakes and river systems (Shephard, 2004). This species is monomorphic for plumage coloration in adult birds; however, like many raptor species, it displays reversed sexual size dimorphism, with female birds being larger than males for a number of morphometric characters (Ferguson-Lees and Christie, 2001; Shephard, 2004). Haliaeetus leucogaster is distributed from the western coast of India throughout the Indo-Malaysia region, Papua New Guinea and Australia (Ferguson-Lees and Christie, 2001). Akin to a large number of other raptors, H. leucogaster has experienced a relatively severe reduction in world population numbers (Ferguson-Lees and Christie, 2001) due to anthropogenic factors that have resulted in fragmentation and loss of suitable habitat (Shephard, 2004). Accordingly, this species is a conservation priority and is protected throughout its range, categorized as "least concern" on the Red List (IUCN, 2010).

Many techniques that are currently used for sex assignment of monomorphic birds have been recently reviewed, but most of these are time-consuming, expensive and invasive to the animals to be tested (Chang et al., 2008). With the current advances in molecular-genetic techniques, most notably the development of polymerase chain reaction (PCR), more discoveries are being made about the organization and composition of animal genomes (Schlötterer, 2004). The resulting DNA sequences have been frequently used to identify species, colony and individuals as well as in sex determination (Duan and Fuerst, 2001; Dubiec and ZagalskaNeubauer, 2006; Shizuka and Lyon, 2008). The most widely used molecular methods for sexing birds exploit the size differences between introns of the CHD gene on the Z- and W-sex 
chromosomes (Shizuka and Lyon, 2008 and references therein). This PCR test employs a single set of primers that amplify homologous fragments of both the CHD-W gene, unique to female, and CHD-Z gene, occurring in both sexes (Sacchi et al., 2004). Thus, the aim of our study was, through the utilization of a non-invasive sampling technique, to describe sex identification of H. leucogaster using this PCR-based test.

\section{MATERIAL AND METHODS}

\section{Sample collection}

Feathers were collected from five known-sex (based on morphometrics characteristics assigned by zoo veterinarians) captive individuals of $H$. leucogaster (four females and one male) from Malacca Zoo, Peninsular Malaysia, and from each known male and female (sexed based on adult plumage) domestic chicken (Gallus gallus), as comparison. Feathers were placed in a sterile plastic bag, which was labeled with a number code specific to that individual, and stored at $-20^{\circ} \mathrm{C}$ before further analysis. Replicate samples from the same individual were also collected and labeled, in order to check for consistency of results.

\section{DNA extraction and PCR amplifications}

Approximately $0.5-1.0-\mathrm{cm}$ segments from two to three individual feathers were cut from the root end and placed in a 1.5-mL Eppendorf tube. Total genomic DNA was extracted using the Tissue DNA kit (Genispin) according to manufacturer instructions with modifications of the pre-lysis step as described by Sacchi et al. (2004).

PCR amplicons were prepared using the $\mathrm{P} 2 / \mathrm{P} 3$ and $\mathrm{P} 2 / \mathrm{P} 8$ primers, as proposed by Griffiths et al. (1998), which simultaneously amplifies the CHD-W and the CHD-Z genes. PCR was performed using $5 \mu \mathrm{L}$ DNA solution obtained from feathers in a final volume of $25 \mu \mathrm{L}$ containing $3.1 \mu \mathrm{L} 10 \mathrm{X}$ polymerase reaction buffer (Fisher Biotech), $2.0 \mu \mathrm{L} 25 \mathrm{mM}$ $\mathrm{MgCl}_{2}$ (Fisher Biotech), 0.1 $\mu \mathrm{L} \mathrm{Taq} \mathrm{DNA} \mathrm{polymerase} \mathrm{(5} \mathrm{U/ \mu L} \mathrm{-} \mathrm{Fisher} \mathrm{Biotech),} 2.0 \mu \mathrm{L} 10$ $\mathrm{mM}$ dNTPs (Fisher Biotech) and $1 \mu \mathrm{L}(10 \mu \mathrm{M})$ of each primer P2/P3 and P2/P8 (Griffiths et al., 1998). We attempted to assess different PCR programs to optimize reactions, and the final thermal cycling conditions were $94^{\circ} \mathrm{C}$ for $1.5 \mathrm{~min}, 47 \mathrm{X}\left[94^{\circ} \mathrm{C}\right.$ for $30 \mathrm{~s}, 53.7^{\circ} \mathrm{C}$ for 30 $\mathrm{s}, 72^{\circ} \mathrm{C}$ for $30 \mathrm{~s}$, and $72^{\circ} \mathrm{C}$ for $5 \mathrm{~min}$, on a Dyad Engine (MJ Research Inc.). Next, $20 \mu \mathrm{L}$ of each PCR mixture was cut with $2 \mathrm{U}$ of the restriction enzyme HaeIII (New England Biolabs), which cleaves the Z-band. Digests were incubated for $1 \mathrm{~h}$ at $37^{\circ} \mathrm{C}$ following the manufacturer recommendation. Digested products of both pairs of primers were visualized and compared with a known marker on a 3\% agarose gel containing ethidium bromide, run at $70 \mathrm{~V}$ for 60 min in 1X TBE buffer. All samples were submitted to PCR and the products digested at least twice to ensure accuracy.

\section{RESULTS}

The analysis of P2/P3 PCR-based products from feathers on a 3\% agarose gel was suitable for sex discrimination in the white-bellied sea eagle and domestic chicken, yielding unambiguous banding patterns in all individuals tested (Figure 1), and the results were consis- 
tent across two or three replications. Female birds showed heterogamety (ZW), whereas male birds did not (ZZ) (Norris-Caneda and Elliot, 1998). Digestion of the PCR products and the use of the restriction enzyme HaeIII to cut the products allowed for sex determination. Thus, resulting from the uncut $\mathrm{W}$-fragment, females had one strong band, and two shorter bands from the cut Z-fragment. Males had two smaller bands (Figure 1). In such case, the Z-chromosome fragment was amplified in both males and females, thus serving as an internal control to verify PCR amplification success (Helander et al., 2007). Sexing results from HaeIII digestion for domestic chicken were consistent with the sexing based on adult plumage.

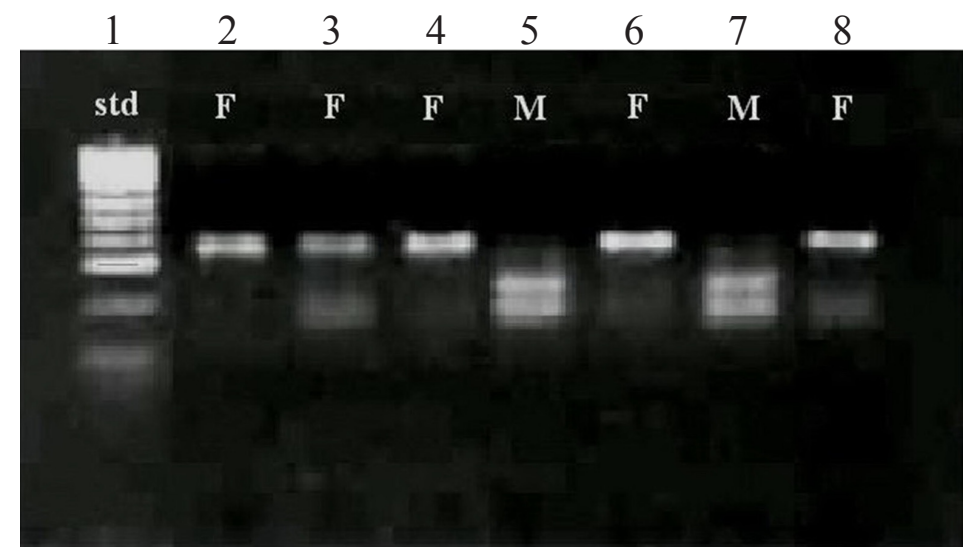

Figure 1. Digested PCR product (lanes 2-6) showing banding pattern for female $(\mathrm{N}=4)$ and male $(\mathrm{N}=1)$ of Haliaeetus leucogaster. Lanes 7 and $8=$ male and female Gallus gallus, respectively. Sub-banding in the female is expected as it carries one Z-band. The molecular weight standard (std, lane 1) is pUC19 (New England Biolabs).

The $\mathrm{P} 2$ and $\mathrm{P} 8$ primer combination used in this study failed to assign sex for all individuals of white-bellied sea eagle and domestic chicken due to amplification failure (data not shown).

\section{DISCUSSION}

Population sex ratios in monogamous birds are often male-biased (Nebel et al., 2004), and thus, knowing the sex ratio of eagle populations is essential in order to achieve successful breeding and establish conservation programs (Chang et al., 2008). This information is even more critical to programs involving small populations of threatened and endangered species, in which the effective population size is limited by the less common sex (Russello and Amato, 2001). Accurate determination of sex ratios in species that do not exhibit sexual dimorphism, such as the white-bellied sea eagle, may present risks to the individual attributable to the use of current invasive techniques (Russello and Amato, 2001). Thus, the need for a non-invasive genetic sexing method, especially in the case of threatened and endangered species, is crucial to the success of many captive breeding programs (Millar et al., 1997; Russello and Amato, 2001; Naim et al., 2011b). In this study, the use of feathers as a source of DNA has been proven as an efficient and effective technique for genetic sexing of the white-bellied sea eagle. This technique has also been applied in other Falconiformes species (see e.g., Sacchi et al., 2004; 
Rudnick et al., 2007; Ong and Vellayan, 2008). Because avian blood cells are nucleated, the total amount of DNA extracted from feathers seems to be sufficient for conducting this research (Ong and Vellayan, 2008).

The PCR-based test for gender determination proposed by Griffiths et al. (1998) and the modified version presented in this study represent valuable tools for ex situ conservation of the white-bellied sea eagle. The use of the $\mathrm{P} 2 / \mathrm{P} 3$ primer combination was suitable for sex discrimination of the white-bellied sea eagle (Figure 1) and 38 other species of raptors (representing four families), which was reported by Norris-Caneda and Elliot (1998). The primer used also provided a high confidence level for establishing the sex of birds even without the use of polyacrylamide gels as required in some bird species (Griffiths et al., 1998; Ong and Vellayan, 2008).

In the comparison of the different primers used to determine the sex of the whitebellied sea eagle in this study, we found that agarose gel electrophoresis of $\mathrm{P} 2 / \mathrm{P} 8$ products did not allow for the differentiation of the sexes (data not shown). This is probably due, in general, to the difference in size between Z- and W-specific fragments amplified with the P2/P8 primers, ranging from 10 to $80 \mathrm{bp}$ (Fridolfsson and Ellegren, 1999). Therefore, due to the ability of polyacrylamide gels, as opposed to agarose gels, to provide better resolution, their use is recommended for separation of the Z- and W-bands (Dubiec and Zagalska-Neubauer, 2006). Likewise, the length difference in P2/P8-amplified Z- and W-fragments, which are extremely short, making it hard to resolve them on agarose gels (Chang et al., 2008), was also reported in other raptors (Fridolfsson and Ellegren, 1999) and specifically in Accipitridae species (Sacchi et al., 2004; García et al., 2009). Moreover, gender assignment based on P2/P8 primers is difficult because of a polymorphism in the Z-chromosome, which has been documented in nearly 20 species of birds (see Dubiec and Zagalska-Neubauer, 2006 and reference therein).

As the PCR-based sexing method is accurate, objective, simple, and non-invasive, it should be proposed for use by managers of captive breeding animals to replace the conventional vent sexing method, which has an accuracy rate of only 98\% (Aun and Kumaran, 2010). Accurate sexing allows managers to establish an equal sex ratio among the captive breeding stock of animals, thus reducing the chances of the formation of same-sex pairs (Millar et al., 1997).

\section{CONCLUSIONS}

Feather specimens are suitable for avian sex determination. This low-cost, speed, and ease of collection, storage, and transport of feather samples are the major advantages (Duan and Fuerst, 2001) compared to the conventional sexing method. Building on the results of the current study, additional research under way in our laboratory will investigate pedigree questions in the captive populations of the white-bellied sea eagle in order to delineate a proper management strategy that will maximize retention of genetic variation (Hedrick, 1992; Taylor and Parkin, 2010).

\section{ACKNOWLEDGMENTS}

Research supported by a Universiti Sains Malaysia Short Term Grant (\#304/ PBIOLOGY/636060). We would like to thank the Director of Malacca Zoo for permission to carry out scientific investigations at the center. We are also grateful to our colleagues, especially Emi Sherizan Ab. Rahim for her technical assistance. 


\section{REFERENCES}

Aun RTS and Kumaran JV (2010). Gender identification of domesticated chicken using a PCR-based method. Pertanika J. Trop. Agric. Sci. 33: 329-336.

Chang HW, Chou TC, Gu DL, Cheng CA, et al. (2008). An improved PCR method for gender identification of eagles. Mol. Cell Probes 22: 184-188.

Duan W and Fuerst PA (2001). Isolation of a sex-linked DNA sequence in cranes. J. Hered. 92: 392-397.

Dubiec A and Zagalska-Neubauer M (2006). Molecular techniques for sex identification in birds. Biol. Lett. 43: 3-12.

Ferguson-Lees J and Christie DA (2001). Raptors of the World. Christopher Helm, London.

Fridolfsson AK and Ellegren H (1999). A simple and universal method for molecular sexing of non-ratite birds. J. Avian Biol. 30: 116-121.

García CB, Insausti JA, Gil JA, de Frutos A, et al. (2009). Comparison of different procedures of DNA analysis for sex identification in the endangered bearded vulture (Gypaetus barbatus). Eur. J. Wildl. Res. 55: 309-312.

Griffiths R, Double MC, Orr K and Dawson RJ (1998). A DNA test to sex most birds. Mol. Ecol. 7: 1071-1075.

Hedrick PW (1992). Genetic conservation in captive populations and endangered species. Appl. Pop. Biol. 67: 45-68.

Helander B, Hailer F and Vilà C (2007). Morphological and genetic sex identification of white-tailed eagle Haliaeetus albicilla nestings. J. Ornithol. 148: 435-442.

IUCN (2010). IUCN Red List of Threatened Species. Version 2010.4. Available at [www.iucnredlist.org]. Accessed January $29,2011$.

Millar CD, Reed CEM, Halverson JL and Lambert DM (1997). Captive management and molecular sexing of endangered avian species: an application to the black stilt Himantopus novaezelandiae and hybrids. Biol. Conserv. 82: 81-86.

Naim DM, Kemp SJ, Telfer S and Watts PC (2009). Isolation and characterization of 10 microsatellite loci in the common dormouse Muscardinus avellanarius. Mol. Ecol. Resour. 9: 1010-1012.

Naim DM, Telfer S, Sanderson S, Kemp S, et al. (2011a). Prevalence of multiple mating by female common dormice, Muscardinus avellanarius. Conserv. Genet. Doi: 10.1007/s10592-011-0200-6.

Naim DM, Telfer S, Tatman S, Bird S, et al. (2011b). Patterns of genetic divergence among populations of the common dormouse, Muscardinus avellanarius in the UK. Mol. Biol. Rep. Doi: 10.1007/s11033-011-0850-y.

Nebel S, Cloutier A and Thompson GJ (2004). Molecular sexing of prey remains permits a test of sex-biased predation in a wintering population of western sandpipers. Proc. Biol. Sci. 271 (Suppl 5): S321-S323.

Norris-Caneda KH and Elliot JD (1998). Sex identification in raptors using PCR. J. Raptor Res. 32: 278-280.

Ong AH and Vellayan S (2008). An evaluation of CHD-specific primer sets for sex typing of birds from feathers. Zoo. Biol. 27: 62-69.

Rudnick JA, Katzner TE, Bragin EA and DeWoody A (2007). Species identification of birds through genetic analysis of naturally shed feathers. Mol. Ecol. Notes 7: 757-762.

Russello MA and Amato G (2001). Application of a noninvasive, PCR-based test for sex identification in an endangered parrot, Amazona guildingii. Zoo. Biol. 20: 41-45.

Sacchi P, Soglia D, Maione S, Meneguz G, et al. (2004). A non-invasive test for sex identification in short-toed Eagle (Circaetus gallicus). Mol. Cell Probes 18: 193-196.

Schlötterer C (2004). The evolution of molecular markers - just a matter of fashion? Nat. Rev. Genet. 5: 63-69.

Segelbacher G (2002). Non-invasive genetic analysis in birds: testing reliability of feather samples. Mol. Ecol. Notes 2: 367-369.

Setiawan AN, Darby JT and Lambert DM (2004). The use of morphometrics measurements to sex Yellow-eyes Penguins. Waterbirds 27: 96-101.

Shephard JM (2004). A Multi-Scale Approach to Defining Historical and Contemporary Factors Responsible for the Current Distribution of the White-Bellied Sea Eagle in Australia. (dissertation). Griffith University, Australia.

Shizuka D and Lyon BE (2008). Improving the reliability of molecular sexing of birds using a W-specific marker. Mol. Ecol. Res. 8: 1249-1253.

Taylor TD and Parkin DT (2010). Preliminary insights into the level of genetic variation retained in the endangered Echo Parakeet (Psittacula eques) towards assisting its conservation management. Afr. Zool. 45: 189-194. 